\title{
Structure Modification of Ethyl p-methoxycinnamate Isolated from Kaempferia galanga Linn. and Citotoxicity Assay of The Products on WiDr Cells
}

\author{
Juni Ekowati $^{1}{ }^{*}$, Marcellino Rudyanto ${ }^{1}$, Shigeru Sasaki ${ }^{3}$, Tutuk Budiati ${ }^{1}$, Sukardiman ${ }^{2}$, \\ Adam Hermawan ${ }^{4}$, Edy Meiyanto ${ }^{4}$ \\ ${ }^{1}$ Department of Pharmaceutical Chemistry, Faculty of Pharmacy, Airlangga University, \\ Jl. Dharmawangsa Dalam, Surabaya 60286, Indonesia \\ ${ }^{2}$ Department of Phytochemistry and Pharmacognosy, Faculty of Pharmacy, Airlangga University, \\ Jl. Dharmawangsa Dalam, Surabaya 60286, Indonesia \\ ${ }^{3}$ Institute of Medicinal Chemistry, Hoshi University, Ebara 2-4-41, Shinagawa, Tokyo 152-8501, Japan \\ ${ }^{4}$ CCRC, Gadjah Mada University, Jl. Sekip Utara, Jogyakarta, 55281 Indonesia
}

\begin{abstract}
Ethyl p-methoxycinnamate, major ingredient of Kaempferia galanga rhizome, have been reported not only has analgesic - anti inflammatory activities like NSAIDs which inhibited cyclooxygenase, but also inhibit tumor cell proliferation in specimen of mouse epidermis. Therefore, it will be interesting to carry out synthetic studies on the derivates of ethyl $p$ methoxycinnamate and searching their citotoxic activity on WiDr cell. We wish to report of structure modification on carboxyl moiety of ethyl p-methoxycinnamate and evaluation on their citotoxic activity on WiDr cell. Isolation of ethyl p-methoxycinnamate from Kaempferia galanga rhizome was carried out by percolation with ethanol $96 \%$ as solvent. Hydrolysis of ethyl $p$-methoxycinnamate in basic condition was performed to obtain p-methoxycinnamic acid. Preparation of some thiourea derivates of ethyl $p$-methoxycinnamate was carried out by microwave irradiation. Citotoxicity assay was carried out by MTT method for $48 \mathrm{~h}$.

Modification of carboxyl group of ethyl p-methoxycinnamate to its thiourea form could be carried out by microwave irradiation gave; (E)-3-(4-methoxyphenyl)- $N$-(phenylcarbamothioyl)acrylamide (50\%); (E)-3-(4-methoxyphenyl)-N-(4-methoxyphenylcarbamothioyl)acrylamide (26\%) and (E)-3-(4-methoxyphenyl)- $\mathrm{N}$-(4-methylphenylcarbamothioyl) acrylamide (54\%), yield calculated for 2 step from the acid chloride. All compounds showed no citotoxic effect on WiDr cell at $48 \mathrm{~h}$ incubation.
\end{abstract}

Keywords: ethyl p-methoxycinnamate, microwave irradiation, Kaempferia galanga, citotoxicity, WiDr cell

\section{INTODUCTION}

Colon cancer or colorectal cancer, is one of type cancer that causes the highest mortality, in addition to beside of breast cancer in women, prostate cancer in men, lung and breast (NCI, 2007). Surgery therapy of colorectal cancer has surgery side effect : infection, anastomosis leakage, obstruction, and malabsorption syndrome. Chronic side effects also usually appear after several months of stopping radiotherapy, including persistent diarrhea, enteritis or proctitis, and wounds that never healed (Medina \& Davis, 2005; Wells, 2006).

Generally, In addition chemotherapy agents have also some typical side effects, including hair loss because of the effects on hair follicles, nausea and vomiting due to stimulation of chemoreceptors prostrema area, diarrhea caused by the effects on the epithelium of the gastrointestinal tract, bone marrow depression in the back that cause neutropenia, thrombocytopenia, and anemia, and fertility disorders (Chabner et al, 2006; Lüllman et al., 2000).

The emergence of serious side effects of cancer treatment has encouraged continued development of research looking for new compounds from natural and synthetic materials as anti cancer.

*Corresponding author e-mail : j_ekowati@yahoo.com 
Ethyl $p$-methoxycinnamate (EPMS), the largest component of the rhizome essential oils kencur (Kaempferia galanga Linn.) rhizome has been reported to have analgesic and antiinflammatory activity (Sadono \& Hasmono, 2001), inhibitor for cyclooxygenase by docking study (Ekowati et al, 2010), inhibitor of tumor promoter teleocidin B-4-induced Epstein-Barr virus (EBV), inhibitor ornitin decarboxylase in the epidermis and skin papillomas of mice (Xue \& Chen, 2001; Vimala et al, 1999) and cytotoxic to Artemia salina by brine shrimp lethality test (Tewtrakul et al., 2005). Those finding give an idea to the author to take advantage of EPMS of kencur rhizome as a starting material for synthesising of compounds that have a cytotoxic effect on colon cancer cells. For example, WiDr cells.

\section{METHOD}

\section{Synthesis}

Starting from ethyl $p$-methoxycinnamate (1) from Kaempferia galangal Linn., the $p$ methoxycinnamoyl isothiocyanates (4) were synthesized through the reaction of $p$-methoxy cinnamoyl chloride (3) and powder ammonium thiocyanate. The final compounds (6a-6c) were obtained by the reaction of some primary amines (5a-5c) and $p$-methoxycinnamoyl thiocyanates (4). (Fig. 1).

The reaction mixture is was irradiated under microwave $140 \mathrm{~W}$. The chemical structures of the synthesized compounds were confirmed by ${ }^{1} \mathrm{H}$ NMR, ${ }^{13} \mathrm{C}-\mathrm{NMR}$, IR and HRMS spectral data, the purity were ascertained by melting point and TLC tests.

Ethyl p-methoxycinnamate was isolated from Kaempferia galanga Linn. under the known method [10]. Kaempferia galanga was collected from Purwodadi Botanical Garden. All reagents and solvent were purchased from standard commercial suppliers. Melting points were measured with a Electrothermal melting point apparatus without correction. IR spectra were recorded in $\mathrm{KBr}$ on Jasco FT-IR 5300, and major absorption was listed in $\mathrm{cm}^{-1} .{ }^{1} \mathrm{H}-\mathrm{NMR}$ and ${ }^{13} \mathrm{C}$ NMR spectra were ${ }^{\prime}$ obtained on BRUKER instrument, and chemical shift were reported in ppm on the $\delta$-scale from internal $\mathrm{Me}_{4} \mathrm{Si}$. MS spectra were measured with a JEOL JMS 600 spectrometer by using the EI methods. TLC was carried out on glass plates coated with silica gel
$F_{254}$ (Merck). Spot detection was performed with UV $254 \mathrm{~nm}$.

\section{Structure Modification of ethyl $p$ - methoxycinnamate Isolated from Kaempferia galangal Linn.}

Ethyl p-methoxycinnamate in 5\% $\mathrm{KOH} /$ ethanol solution was heated for 2 hours by using water bath, then and acidified with $\mathrm{HCl}$ to produce p-methoxycinnammic acid. The crude product was purified by recrystalization using certain solvent and determined its melting point. Mix of p-methoxycinnamic acid in dry benzene and one drop of pyridine, was then added a 5-fold excess of thionyl chloride was added. Care was taken to trap the formation of $\mathrm{HCl}$ vapour formed. The mixture was refluxed overnight, the solvent and excess thionyl chloride were removed by rotary evaporation. The addition of benzene and evaporation process were repeated several times to remove the last traces of thionyl chloride to give a dark yellow solid. p-methoxycinnamoyl chloride was used in the next reaction without purification. After that following the process, powdered ammonium thiocyanate, appropriate $\mathrm{p}$ methoxycinnamoyl chloride, PEG-400 and dichlorometane $(12.5 \mathrm{ml})$ were placed in a dried Erlenmeyer flask and irradiated under microwave at $140 \mathrm{~W}$. Then the appropriate amines (aniline, ptoluidine and p-anisidine) was then added and the mixture was irradiated under microwave $140 \mathrm{~W}$. The mixture was filtered off to remove inorganic salts and the filtrate was concentrated under reduced pressure. The resulting solid was obtained after removing the dichlormethane, then it was recrystalised using ethanol to give pmethoxycynnamoyl thiourea compounds (Fig.1). 
<smiles>COC(=O)/C=C/c1ccc(OC)cc1</smiles><smiles>[R]NC(=S)NC(=O)/C=C/c1ccc(OC)cc1</smiles>

Fig. I. The schematic representation of compounds I-6

\section{Cytotoxicity Assay}

The cytotoxic potencies of the prepared compounds prepared in this study were assessed using a standardized protocol (Reff). Tests were carried out by incubating 5x103 WiDr cells in 96 well plate for 24 hours for adaption, then followed by treatment with the serial concentration of the sample, and further incubatedtion again for 24 hours as described in the research procedure (Reff). Compounds were evaluated at concentrations of $5 \mu \mathrm{M}, 10 \mu \mathrm{M}, 20 \mu \mathrm{M}, 50 \mu \mathrm{M}$, $100 \mu \mathrm{M}$ dan $150 \mu \mathrm{M}$. The viability of cells obtained from the conversion of absorbance values formazan formed by MTT treatment as described in the research procedure (Reff). Profile of cell viability is presented of mean \pm standard deviation (SD) of 3 experiments.

\section{RESULTS AND DISCUSSION} Structure modification of ethyl $p$ -
methoxycinnamate

\section{Transformation ethyl $p$ -} methoxycinnamate (I) to p-methoxycinnamic acid (2).

$p$-methoxycinnamic acid (yield $80 \%$ ) as white crystal (m.p. $169^{\circ} \mathrm{C}$ ). HRMS m/z EI, 178 $\left(\mathrm{M}^{+}\right) .{ }^{1} \mathrm{H}$ NMR (DMSO) $3.78(3 \mathrm{H}, \mathrm{s}), 6.60(1 \mathrm{H}, \mathrm{d}$, $J=16 \mathrm{~Hz}), 6.96(2 \mathrm{H}, \mathrm{d}, J=5.0 \mathrm{~Hz}), 7.53(1 \mathrm{H}, \mathrm{d}$, $J=16 \mathrm{~Hz}), 7.62(2 \mathrm{H}, \mathrm{d}, J=5.0 \mathrm{~Hz}) .{ }^{13} \mathrm{C}$ NMR (DMSO) $55.5 \mathrm{ppm}, 114.54 \mathrm{ppm}, 116.71 \mathrm{ppm}$, $127.02 \mathrm{ppm}, 130.13 \mathrm{ppm}, 143.92 \mathrm{ppm}, 161.12$ ppm, 168.03 ppm, IR (KBr) 2937, 2843, 2567,
1685, 1624, 1288, $1255 \mathrm{~cm}^{-1}$. Calculated Mass $\mathrm{C}_{10} \mathrm{H}_{10} \mathrm{O}_{3}$ 178.0630. Measured Mass 178.0617.

\section{Transformation $p$-methoxycinnamic acid} (2) to p-methoxycinnamoyl chloride (3)

p-methoxycinnamoyl chloride (yield 90\%) as yellow solid (m.p. $51^{\circ} \mathrm{C}$ ). HRMS m/z EI, 196 $\left(\mathrm{M}^{+}\right) .{ }^{1} \mathrm{H}$ NMR $\left(\mathrm{CDCl}_{3}\right) 3.87(3 \mathrm{H}, \mathrm{s}), 6.51(1 \mathrm{H}, \mathrm{d}$, $J=15.2 \mathrm{~Hz}), 6.96(2 \mathrm{H}, \mathrm{d}, J=5.0 \mathrm{~Hz}), 7.53(1 \mathrm{H}$, $\left.{ }^{2} \mathrm{~d}, J=16 \mathrm{~Hz}\right), 7.62(2 \mathrm{H}, \mathrm{d}, J=5.0 \mathrm{~Hz}) .{ }^{13} \mathrm{C}$ NMR (DMSO) $55.5 \mathrm{ppm}, 114.75 \mathrm{ppm}, 116.70 \mathrm{ppm}$, $127.02 \mathrm{ppm}, 130.14 \mathrm{ppm}, 143.94 \mathrm{ppm}, 161.13$ ppm, 168.02 ppm. Calc. Mass $\mathrm{C}_{10} \mathrm{H}_{9} \mathrm{O}_{2} \mathrm{Cl}$ 196.0291. Measured Mass 196.0276.

\section{Synthesis of (E)-3-(4-methoxyphenyl)-N- (phenylcarbamothioyl)acrylamide (6a)}

(yield 50\%) as pale green crystal (m.p. $\left.200^{\circ} \mathrm{C}\right)$. MS m/z EI, $312\left(\mathrm{M}^{+}\right) .{ }^{1} \mathrm{H}$ NMR $\left(\mathrm{CDCl}_{3}\right)$ $3.87(3 \mathrm{H}, \mathrm{s}), 6.31(1 \mathrm{H}, \mathrm{d}, J=15.60 \mathrm{~Hz}), 7.30(1 \mathrm{H}$, $\mathrm{d}, J=15.60 \mathrm{~Hz}), 7.71(2 \mathrm{H}, \mathrm{d}, J=9.60 \mathrm{~Hz}), 6.94$ $(2 \mathrm{H}, \mathrm{d}, J=9.60 \mathrm{~Hz}), 7.50(2 \mathrm{H}, \mathrm{d}, J=9.60 \mathrm{~Hz})$, $7.41(2 \mathrm{H}, \mathrm{t}, J=6.80 \mathrm{~Hz}), 7.28(1 \mathrm{H}, \mathrm{t}, J=10.80$ $\mathrm{Hz}), 8.69(1 \mathrm{H}, \mathrm{s}), 12.63(1 \mathrm{H}, \mathrm{s})$. IR $(\mathrm{KBr}) 3222$, $3031,1671,1591,1537,1244,1149,826 \mathrm{~cm}^{-1}$. ${ }^{13} \mathrm{C}$ NMR (DMSO) $55.46 \mathrm{ppm}, 114.96 \mathrm{ppm}$, 124.16 ppm, 126.37 ppm, 126.79 ppm, 128.86 ppm, 130.41 ppm, 137.68 ppm, 146.45 ppm, $162.19 \mathrm{ppm}, 166.02 \mathrm{ppm}, 178.66 \mathrm{ppm}$. Calc. Mass $\mathrm{C}_{16} \mathrm{H}_{15} \mathrm{NO}_{3}$ 312.0932. Measured Mass 312.0928. 
Synthesis of (E)-3-(4-methoxyphenyl)-N(4-methylphenylcarbamothioyl)acrylamide (6b) (yield 54\%) as pale yellow crystal (m.p. $\left.165^{\circ} \mathrm{C}\right) \mathrm{MS} \mathrm{m} / \mathrm{z}$ EI, $326\left(\mathrm{M}^{+}\right) .{ }^{1} \mathrm{H}$ NMR $\left(\mathrm{CDCl}_{3}\right) 2.37(3 \mathrm{H}, \mathrm{s}), 3.87(3 \mathrm{H}, \mathrm{s}), 6.31(1 \mathrm{H}, \mathrm{d}, J=$ $15.40 \mathrm{~Hz}), 6.93(2 \mathrm{H}, \mathrm{d}, J=9.60 \mathrm{~Hz}), 7.21(2 \mathrm{H}, \mathrm{d}$, $J=8 \mathrm{~Hz}), 7.78(1 \mathrm{H}, \mathrm{d}, J=15.40 \mathrm{~Hz}), 7.54(4 \mathrm{H}$, $\mathrm{m}), 8.68(1 \mathrm{H}, \mathrm{s}), 12.51(1 \mathrm{H}, \mathrm{s})$. IR $(\mathrm{KBr}) 3224$, $3025,1672,1590,1537,1248,1151,827 \mathrm{~cm}^{-1} \cdot{ }^{13} \mathrm{C}$ NMR (DMSO) 55.43, 114.51, 115.53, 124.25, $126.42,129.44,130.39,135.10,146.27,162.12$, 166.08, 178.78 ppm. Calc. Mass $\mathrm{C}_{16} \mathrm{H}_{15} \mathrm{NO}_{3}$ 326.1095. Measured Mass 326.1089.

\section{Synthesis of (E)-3-(4-methoxyphenyl)-N- (4-methoxyphenylcarbamothioyl)acryla- mide (6c)}

(yield 26\%) as pale yellow crystal (m.p. $181^{\circ} \mathrm{C}$ ) MS m/z EI , $342\left(\mathrm{M}^{+}\right) .{ }^{1} \mathrm{H}$ NMR (DMSO) 3.76 $(3 \mathrm{H}, \mathrm{s}), 3.80(3 \mathrm{H}, \mathrm{s}), 6.86(1 \mathrm{H}, \mathrm{d}, J=15.80 \mathrm{~Hz})$, 6.95-7.03 $(4 \mathrm{H}, \mathrm{m}), 7.51-7.59(4 \mathrm{H}, \mathrm{m}), 7.70(1 \mathrm{H}, \mathrm{d}$, $J=15.80 \mathrm{~Hz}), 11.43(1 \mathrm{H}, \mathrm{s}), 12.58(1 \mathrm{H}, \mathrm{s}) \cdot{ }^{13} \mathrm{C}$ NMR (DMSO) 55.49, 55.61, 114.01, 114.84, $117.23,125.92,126.88,130.33,130.94,144.60$, $157.59,161.65,166.83,179.23 \mathrm{ppm} . \quad \mathrm{IR}(\mathrm{KBr})$ $3235,3034,1673,1593,1509,1252,1150,825$ $\mathrm{cm}^{-1}$. Calc. Mass $\mathrm{C}_{16} \mathrm{H}_{15} \mathrm{NO}_{3}$ 342.1038. Measured Mass. 342.1031.

Unlike reported reaction condition where some thiourea preparation was at room temperature (Xu et al., 2003), in this research Unlike reported the reaction condition to prepare some thiourea compounds which in room temperature (Xu et al., 2003), preparation of thiourea compounds from EPMS was done by on microwave irradiation. In 2004, Wei et al successfully developed methods of synthesis of $\mathrm{N}$ phenyl- $N$-benzoylthiourea with microwave irradiation method. In this process synthesis of compounds $\quad N$-phenyl- $N$ '-benzoylthiourea the reaction takes about 10 minutes with the percentage yield about results obtained around $98 \%$.

Microwave irradiation increases the speed of reaction and increase the reaction with a small side reaction products. The situation can be explained by an influence of thermal heat and / or non-thermal effects or specific microwave effect. Heating by microwave irradiation involves two mechanisms namely dipole rotation and ionic conduction. Absorption of microwave energy occurs when a rotating dipole molecules align themselves with the electric field components or ions move back and forth because the same phenomenon. When molecules or ions rotate back and forth in the matrix, it will arise because the heat caused by friction (Mavandadi, 2004).

Preparation of some thiourea derivates of EPMS from kencur rhizome, i.e. compound 6a, $6 \mathrm{~b}$ and $6 \mathrm{c}$ (Fig.1) takes place in two stages. First step is nucleophylic substitution reaction between p-metoksisinamoil ammonium chloride with thiocyanate. The nucleophilic substitution reaction is a substitution reaction of a nucleophile which has a pair of free electrons (atoms $\mathrm{N}$ in ammonium thiocyanate) on the $\mathrm{C}$ atom of $p$ methoxycinnamoyl chloride that binds chlorine atom. The reaction will release the halide ions of the acyl halide, the chloride ion, so that, it will be generated to become $p$-methoxycinnamoyl isothiocyanate. In the second phase step, occurs is the addition of nucleophiles, where the nucleophile is the $\mathrm{N}$ atom on aniline (5a), $p$-methylaniline (5b) and $p$-methoxyaniline (6c), this will attacks the $\mathrm{C}$ atom bound of $p$-methoxycinnamoyl isothiocyanate to atom $\mathrm{N}$, produced (E)-3-(4methoxyphenyl) $-N$ -

(phenylcarbamothioyl)acrylamide, $(E)-3-(4-$

methoxyphenyl)- $N$-(4-methylphenylcarbamothi oyl)acrylamide and (E)-3-(4-methoxyphenyl)- $N$ (4-methoxyphenylcarbamothioyl)acrylamide.

Differences of amine functional groups on compounds that are used, to can give different percentage results obtained. This was because of the differences in the nature of these functional groups, methyl substituents $(-p)$ on aniline compound is an electron donating substituent allowing the nucleophilic addition of amine compounds on the p-methoxycinnamoyl isothiocyanate. Substituent methoxy (-p) on aniline compound is also donating an electron, but in this study the lowest percentage of the results. This is probably due to the high solubility of this compound (6c) in ethanol, used during recrystallization.

\section{Cytotoxic Assay for WiDr Cells}

Cytotoxicity test was done to confirm the cytotoxic ability of 3 compounds derivates of ethyl $p$-methoxycinnamate against $\mathrm{WiDr}$ cells. Cytotoxic test can be carried out used by colorimetric method, which is based on the ability of mitochondrial dehydrogenase enzymes to convert MTT (3 - (4,5-dimetiltiazol-2-yl) -2.5 diphenyl tetrazolium-bromid ), a yellow substrate that is not soluble in water, to a dark blue formazan that is not soluble in water and attached to the cells (Doyle and Griffiths, 2000). Formazan formed is proportional to the number of living 
cells, since the reduction MTT into formazan can only be done by living cells, (Mosmann, 1983). The method is rapid, sensitive, accurate and can be used for test samples in large numbers automatically using spectrophotometer ELISA Reader (Doyle and Griffiths, 2000). This method also proved more reliable than cell calculations using hemositometer (Freimoser et al., 1999).

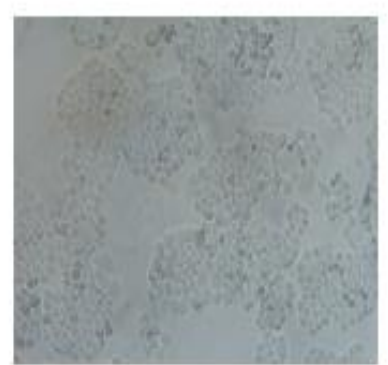

control cell

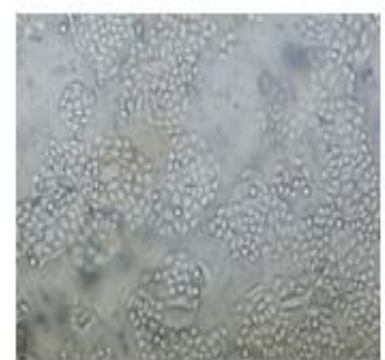

$6 a$

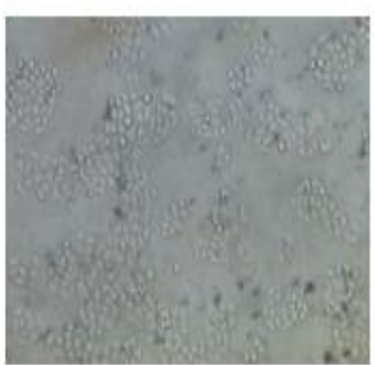

6b

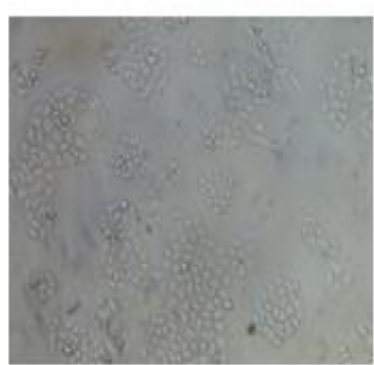

6c

Fig. 2. Morphology WiDr cell after incubated with sample 6a, 6b and 6c (up to $150 \mu M$ for $24 \mathrm{~h}$ by inverted microscope $(400 x)$. No difference between control cell WiDr and those sample (6a, $6 \mathrm{~b}$ and $6 \mathrm{c})$.

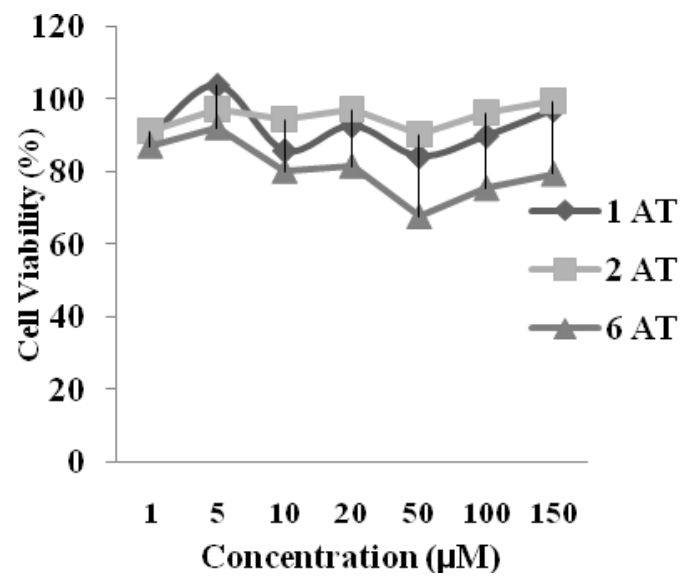

(A)

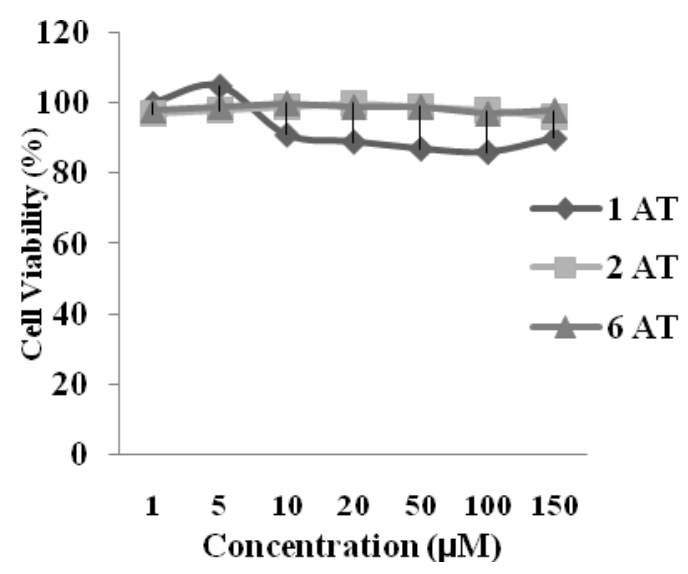

(B)

Fig. 3. Effect of sample treatment $6 a, 6 b$ and $6 c$ on viability WiDr cell for $24 \mathrm{~h}(\mathrm{~A})$ and $48 \mathrm{~h}$ (B).

Table I. IC 50 value of Samples

\begin{tabular}{cc}
\hline Compounds & IC $50(\mu \mathrm{M})$ \\
\hline $6 \mathrm{a}$ & - \\
$6 \mathrm{~b}$ & - \\
$6 \mathrm{c}$ & - \\
\hline
\end{tabular}




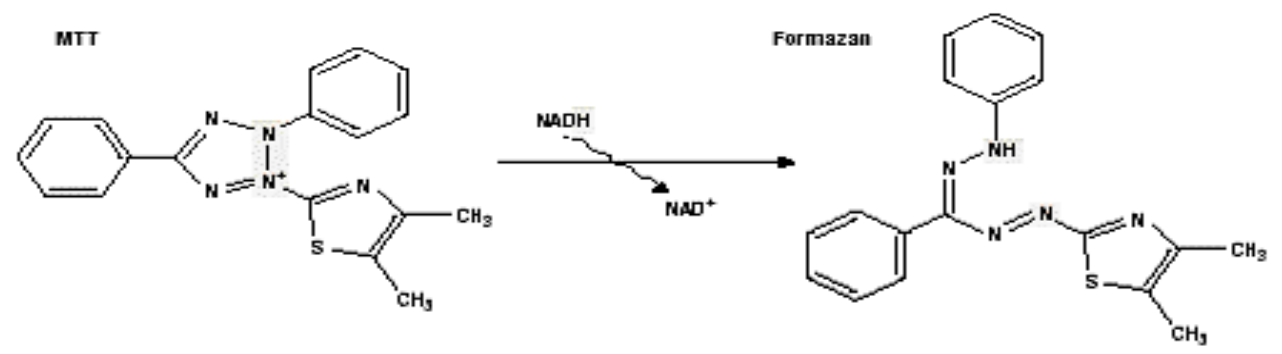

Fig. 5. MTT reduction reaction to formazan by succinate dehydrogenase enzyme (Mosmann, 1983).

Reduction MTT into formazan can be done only by living cells. Thus, the absorbance of formazan formed is proportional to the population viability of cells (Mossman, 1983). There are variation of the enzymatic capability is expected to differ in each cell is still alive. Solvents used were DMSO. The highest DMSO concentration used in this study was $0.12 \%(\mathrm{v} / \mathrm{v})$, has no effect on the test cell.

WiDr cell is one of cells that has a low sensitivity towards treatment with 5-fluorouracil (5-FU), antimetabolite class of chemotherapeutic agents. Transfection of WiDr with normal p53 did not cause increasing sensitivity to 5-FU (Giovannetti et al., 2007). WiDr cell resistance against 5-FU one of which is mediated by the increased expression of the enzyme thymidylate synthetase, which is the main inhibitory target of 5-FU (Sigmond et al., 2003). However, Pglycoprotein (PGP) in $\mathrm{WiDr}$ cells did not too express high, so that there might be other mechanisms that facilitate resistance to $5-\mathrm{FU}$ (Jansen, 1997).

The existence of the relationship between dose and percent of the living cell occurs if a longer incubation period was carried out, so that the activity was seem to be was carried out, so that the activity was seem to be (time-dependent). IC50 is the parameter used to demonstrate the anticancer potential of a test substance. IC50 of a test substance can be calculated if there is a correlation between levels with the percentage of living cells. IC50 of the test substance is still more likely to be developed as a cancer drug is equal to $100 \mathrm{ug} / \mathrm{ml}$ (Ueda et al, 2002).

\section{CONCLUSION}

1. Modification of carboxyl group of ethyl $p$ methoxycinnamate to its thiourea form can be carried out by microwave irradiation to give; a. (E)-3-(4-methoxyphenyl)- $N$ (phenylcarbamothioyl)acrylamide (6a) $(50 \%)$

b. (E)-3-(4-methoxyphenyl)- $N-(4-$ methoxyphenylcarbamothioyl)acrylami de (6b) $(26 \%)$

c. (E)-3-(4-methoxyphenyl)- $N$-(4methylphenylcarbamothioyl)acrylamid e (6c) $(54 \%)$

2. All compounds showed no cytotoxic effect for WiDr cell after treatment for 24 and $48 \mathrm{~h}$.

3. Substituent -phenyl, -methylphenyl $(-p)$ and methoxyphenyl $(-p)$ on compounds (6a-c) have no influence on viability WiDr cells.

\section{REFFERENCES}

Chabner, B.A., Amrein, P.C., Druker, B.J., et al., 2006, Chemotherapy of Neoplastic Diseases. In: Brunton, L.L., Lazo, J.S., Parker K.L., Goodman and Gilman's the Pharmacological Basis of Therapeutics, $1^{\text {th }}$ Ed, New York: The McGraw- Hill Co., Inc. Chapter 5I.

Doyle, A., and Griffiths, J.B., 2000, Cell and Tissue Culture for Medical Research, John Willey and Sons Ltd, New York.

Freimoser, F.M., Jakob, C.A., Aebi, M. and Tuor, U., 1999, The MTT \{3-(4,5Dimethylthiazol-2-yl)-2,5-

Diphenyltetrazolium Bromide $\}$ Assay Is a Fast and Reliable Method for Colorimetric Determination of Fungal Cell Densities, Applied and Environmental Microbiology, 65(8), 3727-3729.

Giovannetti, E., Backus, H.H.J., Wouters, D., Ferreira, C.G., van Houten, V.M.M. and Brakenhoff, R.H., 2007, Changes in the Status of p53 Affect Drug Sensitivity to Thymidylate Synthase (TS) Inhibitors by Altering TS Levels, British J. Can., 96, 769775.

Lullman, H., Mohr, K., Zielger, A., Bieger, D., 2002, Color Atlas of Pharmacology, $2^{\text {nd }} E d$, 
New York: Thieme Stuttgard., Pp. 296299.

Mavandadi, F. and Lidstrom, P., 2004, MicrowaveAssisted Chemistry in Drug Discovery. Medical Chemistry, 4, 773-792.

Medina, P.J. and Davis, L.E., 2005. Colorectal Cancer. In: Dipiro, J.T., Talbert, R.L., Matzke G.R., Wells, B.G., Posey, L.M (Eds), Pharmacotherapy A Pathofisiologic Approach, $6^{\text {th }}$ Ed, New York: The McGraw-Hill Co., Inc. p.2383-24I5.

Mosmann, T., 1983, Rapid Colorimetric Assay for Cellular Growth \& Survival: Application to Proliferation \& Cytotoxicity Assays, Journal of Immunological Method, 65, 65-59.

$\mathrm{NCl}$ fact sheet 2007, What is cancer? accessed from http://www.nci.org October 2008

Sigmond, J., Backus, H.H., Wouters, D., Temmink, O.H., Jansen, G. and Peters, G.J., 2003, Induction of Resistance to the Multitargeted Antifolate Pemetrexed (ALIMTA) in WiDr Human Colon Cancer Cells is Associated with Thymidilate Synthase Overexpression, Biochem. Pharmacol. 25(I2), 189-20I.

Tewtrakul, S., Yuenyongsawad, S., Kummee, S. and Atsawajaruwan, L., 2005, Chemical component and biological activities of volatile oil of kaempferia galanga Linn. Songklanakarin J.Sci.Technol., 27(Suppl.2), Thai herbs. 504-507.

Ueda, J.Y., Tezuka, Y., Banskota., A.H., Tran, Q.L., Tran, Q.K., Harimaya, Y., Saiki, I. and Kadota, S, 2002, Antiproliferative Activity of Vietnamese Medicinal Plants, Biol. Pharm. Bull. 25(6), 753-760.

Vimala, S., Norhanom, A.W. and Yadav, 1999, Antitumor promoter activity in Malaysian ginger rhizobia used in traditional medicine. Br. J. Cancer, 80(I-2), II0-II6.

Wells, B.G., DiPiro, J., Schwinghammer, T. And Hamilton, C., 2006, Pharmacotherapy Handbook, $6^{\text {th }}$ Ed, Boston: The McGrawHill Co. pp.6I4-62I.

Wei, T.B., Lin, Q., Zhang, Y.M. and Wei, W., 2004, Microwave Promoted Efficient Synthesis of N-Aryl-N'-Aroyl thiourea under Solvent-Free and Phase Transfer Catalysis Conditions, Journal of Synthesic Communication, 34(I), I8I-186.

Xue, Y. and Chen, H., 200I, Abstracts of the XVIth EUCARPIA Congress.Edinburg. Scotland.

Xu, X., Qian, X., Li, Z., Huang, Q. and Chen, G. 2003, J. of Fluorine Chemistry, I 2 I, 5I-54. 